Lisbon - Malacca Port Cities Twin Conferences 2019 / 2020

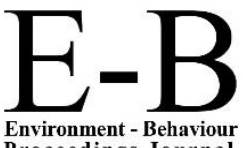

AicQoL2020Malacca

ASLI (Annual Serial Landmark International) Conferences on QoL2020

https://www.amerabra.org; https://sspu.uitm.edu.my/cebs; https://www.emasemasresources.com/

8th AMER International Conference on Quality of Life

Mahkota Hotel Melaka, Malacca, Malaysia, 18-19 Mar 2020

(Due to the Covid-19 lockdown, paper virtually presented on 25 Mar 2020)

\title{
The Observation of Sensory Design in Open Spaces of University Campus under Hot-humid Climate
}

\author{
Fan Mengjia1, Adi Ainurzaman Jamaludin², Hazreena Hussein ${ }^{3}$ \\ 1Department of Architecture, Faculty o Built Environment, \\ University of Malaya, Malaysia \\ 2 Environmental Science and Management Program, Institute of Biological Sciences, Faculty of Science, \\ University of Malaya \\ ${ }^{3}$ Centre for Sustainable Urban Planning \& Real Estate, Faculty o Built Environment, \\ University of Malaya, Malaysia
}

fanmengjia1990@gmail.com; adiainurzaman@um.edu.my; reenalambina@um.edu.my

Tel. +60183200086

\begin{abstract}
This paper aims to explore the current sensory design of open spaces surrounding educational buildings. Observation of sensory landscape variables is conducted to investigate the potential of supporting outdoor experience. The expected key findings include the functional design and the stimulated multi-senses in the presence of university campuses under a hot-humid climate. In recommendation, the conjunction of behavioural mapping and questionnaire surveys in future studies may lead to more findings of the interaction of users' behaviours and activities, as well as the correlations between sensory stimulation, environmental satisfaction, and outdoor experience.
\end{abstract}

Keywords: Sensory stimulation; outdoor experience; open space; university campus

eISSN: 2398-4287 @ 2020. The Authors. Published for AMER ABRA cE-Bs by e-International Publishing House, Ltd., UK. This is an open access article under the CC BYNC-ND license (http://creativecommons.org/licenses/by-nc-nd/4.0/). Peer-review under responsibility of AMER (Association of Malaysian Environment-Behaviour Researchers), ABRA (Association of Behavioural Researchers on Asians) and cE-Bs (Centre for Environment-Behaviour Studies), Faculty of Architecture, Planning \& Surveying, Universiti Teknologi MARA, Malaysia. DOI: https://doi.org/10.21834/e-bpj.v5i13.2043

\subsection{Introduction}

\subsection{Research Background}

The shrinking of green spaces in an urban area is causing the prevalence of unhealthy lifestyle, especially in the tropical region where the extreme weather leads to indoor sedentary behaviour as well. Outdoor experience in green space can facilitate the enhancement of physical and mental health as well as social wellbeing. A university campus located in the city centre can preserve a certain amount of green space. It is potential to provide an outdoor environment for wellbeing promotion among students and staff.

Open spaces between buildings are universally applied in hot-humid areas for achieving indoor thermal comfort and optimizing a passive design for the built environment. Open spaces between buildings are convenient to reach and easy to access. The practical use and design make these open spaces to be beneficial for students and staff to facilitate physical, mental, and social wellbeing by providing precious outdoor experiences.

eISSN: 2398-4287 @ 2020. The Authors. Published for AMER ABRA cE-Bs by e-International Publishing House, Ltd., UK. This is an open access article under the CC BYNC-ND license (http://creativecommons.org/licenses/by-nc-nd/4.0/). Peer-review under responsibility of AMER (Association of Malaysian Environment-Behaviour Researchers), ABRA (Association of Behavioural Researchers on Asians) and cE-Bs (Centre for Environment-Behaviour Studies), Faculty of Architecture, Planning \& Surveying, Universiti Teknologi MARA, Malaysia.

DOI: https://doi.org/10.21834/e-bpj.v5i13.2043 
In hot-humid areas, climatic factors (i.e., thermal discomfort, high temperatures, and relative humidity) and inconvenient design (i.e., lack of shielding or protection from rain and solar radiation) have reduced the benefits of outdoor experience and the use of these spaces (Nasir et al., 2012). Plenty of previous pieces of evidence have described the relationship between wellbeing and open space, as well as the variables affecting outdoor experience (Othman \& Fadzil, 2015; 2018; Nasir et al., 2016). Nonetheless, the criteria of landscape design on improving sensory stimulation to encourage outdoor experience have not been sufficiently studied, especially from university campus contexts.

\subsection{Research question and aim}

Sensory stimulation is the activation of one or more of the senses including taste, smell, vision, hearing, and touch. Every sense in a space can be designed to provide the users with more comfortable experience while they are using the place. In the landscape design of campus open space, to understand users' perception of the physical environment, sensory stimulation is essential to be studied to encourage outdoor activities among campus users and to create more interactive campus open space. Yet the approaches for improving sensory stimulation still need to be studied in the context of university campus. Especially, there is no specific investigation and analysis has been conducted under the environmental context for a university campus in an urban area with hot-humid climates. As the role of sensory stimulation in university open spaces is inadequately defined, this paper aims at investigating the sensory design in campus open space to support outdoor experience, which is potential to improve the environmental satisfaction and promote wellbeing in urban universities in hot-humid area.

\subsection{Literature Review}

\subsection{Sensory stimulation and outdoor experience}

Shreds of evidence are showing that relevant practices of sensory design have been implemented into campuses and therapeutic gardens for students with special needs (Hussein, 2010). However, "inclusive design is not necessarily solely meant for people with disabilities," sensory stimulation and its additionally offered experience can benefit the ordinary public as well (Omar \& Hussein, 2017). The design variants and spatial organization of gardens and yards provide stimulation of various senses forms an inclusive atmosphere to improve the quality of sensory experience (Hussein et al., 2016). Based on the findings by Wang \& Li (2018), vegetation and water are the most popular natural elements of sensory design.

Components such as hard/soft landscape, colours, textures, and wildlife can represent sensory experiences during the process of landscape design for a self-contained area (Hussein, 2010). Gonzalez \& Kirkevold (2016) have recommended design guidelines involving sensory experiences, stable walkways, landmarks, accessibility and visibility from indoors, seating features, and prosthetic supports. Many evidence expound that sensory design has been applied to the educational environment to achieve better interaction with various education means (Ghazali \& Abbas, 2012). Similarly, the landscape variables in campus open spaces may be improved by sensory design to achieve maximum support for beneficial outdoor activities and behaviours via sensory stimulation. To make advantageous use of the outdoor environment is dependent upon users' physical proximity, social inclusion, and the perception to gain physical, social, and emotional access (Nasir et al., 2012). Because of the human-catering consideration, the successful sensory design is likely to be the key to improving campus open spaces.

\subsection{Educational buildings in hot-humid area}

In the hot-humid area, surrounding open space in the built environment has been testified to be an essential determinant of indoor ventilation and thermal comfort. Open spaces are more common for building layout in hot-humid climate and provide ideal venues for physical activity, self-restoration and social life. However, the lack of outdoor experience is more prevalent in tropical areas due to the climatic and habitual reasons, such as thermal discomfort and less physical activity (Muslim et al, 2017).

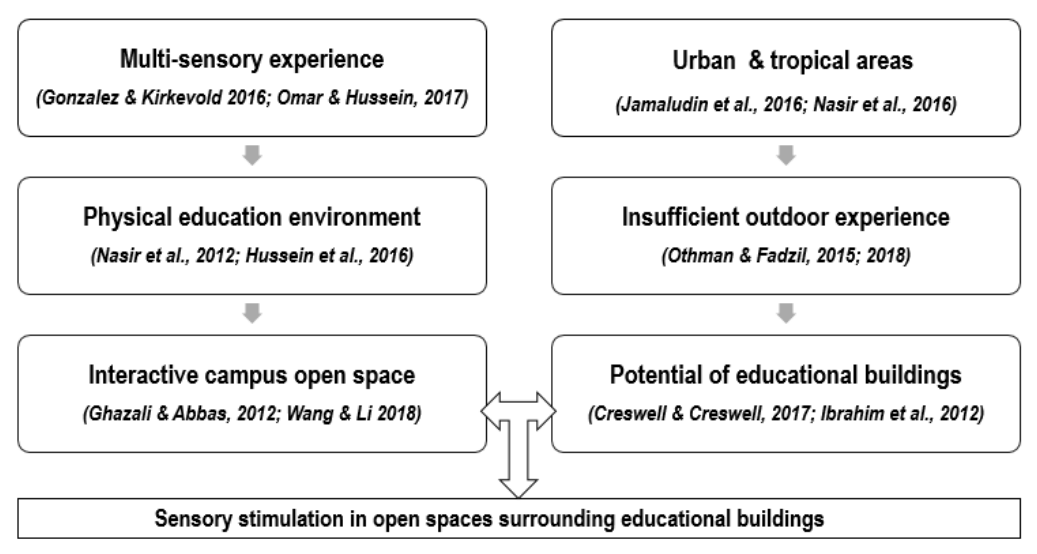

Fig. 2.1: Framework of Literature Review (Source: Author) 
Open spaces between buildings are universally applied in hot-humid areas for achieving indoor thermal comfort and optimising the passive design of the built environment. The surrounding open spaces of educational buildings have the potential to provide more opportunities for outdoor activities by providing daytime shade and aiding human thermal comfort. University of Malaya (UM) is under the influence of hot-humid climate all year round with relatively high air temperature, relative humidity, and solar radiation (Jamaludin et al., 2016). According to Universitas Indonesia GreenMetric World University Ranking (UIGM), UM has maintained the position as the first of most sustainable universities in Asia (University of Malaya, 2019). Not only the sustainable development system is well applied in UM, but its campus environment is also one of the main focuses of investigations. Based on the findings of the pilot study, the UM campus seems to be suitable for choosing a case-study site to carry out a pilot site study about the assessment of sensory design in an outdoor environment., the framework of justification is shown in Fig. 2.1.

\subsection{Methodology}

\subsection{Research method}

In open space studies, utilization of open space is under the impact of design-related factors such as location, safety, distance, size, accessibility, management and maintenance, comfort, legibility, types of activities, and facilities provided (Malek ar al, 2018). Site observation is a method commonly used to explore the usage or function of a space. To investigate the current landscape design of open spaces, a quantitative assessment of all marked settings in site observation is essential to establish representativeness (Kawulich, 20005). Therefore, in this investigation, the observation of campus open space is conducted in line with two sets of guideline forms, to evaluate the potentials of improvement on sensory design.

During the process of data collection, the first step is to collect descriptive data about the selected educational building. The second step is to obtain detailed information about chosen open spaces. After preliminary site study about educational buildings in several university campuses in the urban area of Kuala Lumpur, the educational structures are found to be related to the assessment of surrounding open spaces from the aspects of both physical environment and educational activities. Accordingly, the guideline forms are developed during this process to record the general description and characteristics of selected educational buildings and adjacent open spaces. In this paper, the Faculty of Medicine in UM is taken as an example to demonstrate the process of data collection and the investigation result can be used to justify the chosen method.

\subsection{Research limitation}

To guarantee the accuracy of the areas and ratio of soft/hard landscape, official data need to be obtained from the faculty administration office to minimize the limitations on measurement. Additionally, data about the area of surrounding open space and the number of regular users was hard to record, secondly, sometimes the author had difficulties in identifying the species of local plants.

Site observation is used to record the usage of a site and discovers the functioning of open space. Still, it is less useful for learning about people's perceptions, feelings, and motivations (Creswell \& Creswell, 2017). Hence, Therefore in this study, there is a limitation in getting the information about the connection between environment settings and behaviours, as well as environmental satisfaction contributed by variables of sensory stimulation.

\subsection{Findings}

\subsection{Investigation results in Faculty of Medicine, University of Malaya}

Programs setting and research areas of the Faculty of Medicine concentrate on medicine and surgery, biomedical science, pharmacy, nursing science. The first step involves the collection of the necessary information about the main educational building. The regular lecture hours are scheduled between 8.00 am and 5.pm from Monday to Thursday with one hour break from $1.00 \mathrm{pm}$ to $2.00 \mathrm{pm}$, as well as on Friday with a more extended break from noon. This educational building is located in the southeast corner of the UM campus next to the Medical Center. Open corridors of the leading educational building are well connected with the outside environment. There are three surrounding open spaces; one of them can be used for a case study, as shown in Figure 4.1. Open corridors and stairs take a large part of the total building area because of the combination with the outside layout, which has oblivious height differences. Attached open passages with a rotating sun shield on the open corridor to adjust light and temperature are arranged between indoor and outdoor space, as shown in Figure 4.2.

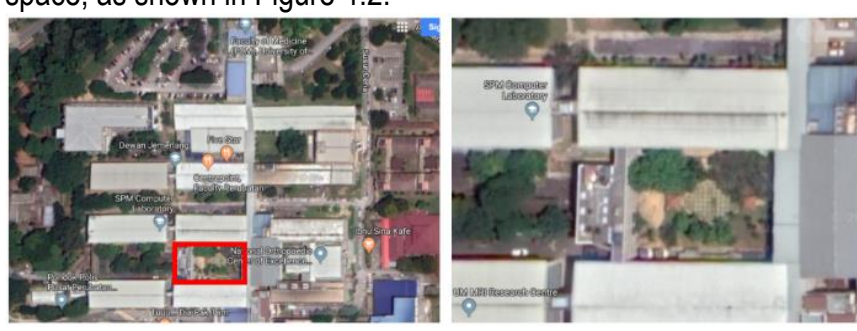

Fig. 4.1. The layout of the Faculty of Medicine and selected open space (Source: Google map)
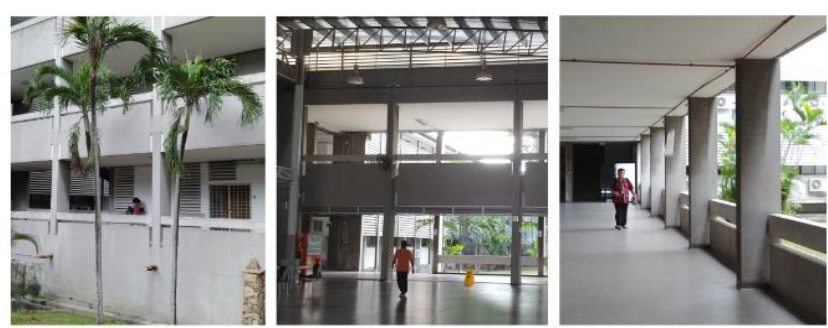

Fig. 4.2. Façade design of Faculty of Medicine, University of Malaya (Source: Author) 
The selected open space (coded as FM-OS1) is an accessible open space with sufficient facilities to enable participation and to be convenient for outdoor activities. The layout and spatial location with building and site context, landscape design, sensory stimulation, and evaluation of potential as a case study are shown in Table 4.1. The layout and design details are shown in Figure 4.3. The plants' species are shown in Table 4.2.

Table 4.1: Selected open space FM-OS1

\begin{tabular}{|c|c|c|}
\hline No. of open space & \multicolumn{2}{|l|}{ FM-OS1 } \\
\hline $\begin{array}{l}\text { Layout and spatial location with } \\
\text { building and site context }\end{array}$ & \multicolumn{2}{|c|}{$\begin{array}{l}\text { Squared courtyard connecting to the side entrance, on the underground level. } \\
\text { Layout and landscape design are shown in Figure } 4.3 \text {. }\end{array}$} \\
\hline \multirow{3}{*}{ Area and ratio } & Total area (m2) & 221.5 \\
\hline & Hard landscape (m2) & 530 \\
\hline & Soft/hard landscape & $2.39 \%$ \\
\hline Plants species & \multicolumn{2}{|l|}{ Shown in Table 4. 2} \\
\hline Human-made features & \multicolumn{2}{|c|}{ Stone tables and chairs, two pavilions, a path with a stone frame, stone artwork, short stone wall. } \\
\hline Accessibility & \multicolumn{2}{|c|}{ Accessible - with sufficient facilities to enable participation and to be convenient for outdoor activities. } \\
\hline \multirow{2}{*}{ Participation description } & Typical activities & Charting, having meals, group meetings, telephone calls, reading, walking. \\
\hline & $\begin{array}{l}\text { The average length of } \\
\text { engagement }\end{array}$ & $\begin{array}{l}\text { Many students use this space during breaks in the middle, and in the morning time } \\
\text { before school, more participants prefer to use the northeast corner. }\end{array}$ \\
\hline \multirow[t]{8}{*}{$\begin{array}{l}\text { Sensory evaluation in the } \\
\text { presence of campus open space }\end{array}$} & Sight & $\begin{array}{l}\text { The southern part is a sharp slope covered by groups of trees and shrub, and the } \\
\text { north part has a more hard landscape. But two pavilions and the grass square has } \\
\text { made an axis of view, and the layout on both sides are balanced. }\end{array}$ \\
\hline & Texture of plants & $\begin{array}{l}\text { Delicate small leaves of plants with the rough, beautiful shaped trunk, and branches } \\
\text { are the most significant feature of species. }\end{array}$ \\
\hline & Touch & The hard cold, smooth surface of facilities \\
\hline & Smell & Without any special smell \\
\hline & Sound & Noise from the open corridor \\
\hline & Shadow casting & Shadow of trees can over $30 \%-50 \%$ of the total area during the daytime. \\
\hline & Microclimate & Airy and cool \\
\hline & Temperature & Highest 33c Lowest 27c Average 29.5c \\
\hline \multirow[t]{3}{*}{ Feedback from the users } & Problems encountered & (combine with questionnaire survey) \\
\hline & Purposes of use & (combine with questionnaire survey) \\
\hline & Benefits obtained & (combine with questionnaire survey) \\
\hline Potential as a case study & \multicolumn{2}{|c|}{ Yes. It has enough facilities and comfortable microclimate for serving more users. } \\
\hline
\end{tabular}
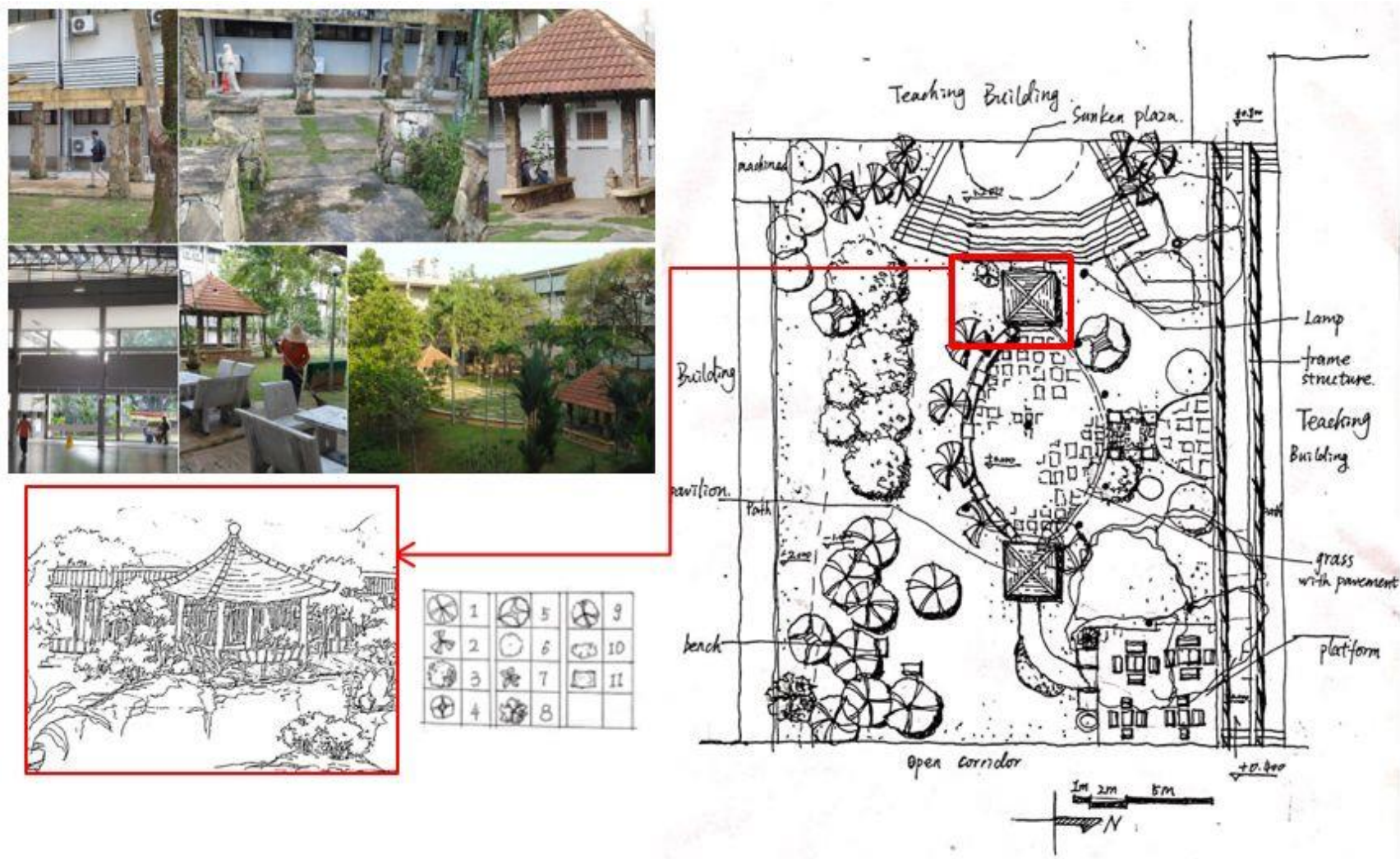

Fig. 4.3: Layout and design of open space FM-OS1

(Source: Author) 
Table 4.2: Plants species of FM-OS1

\begin{tabular}{|c|c|c|c|c|}
\hline No. & Scientific Name & Common Name & $\begin{array}{l}\text { Amount } \\
\text { (number or area) }\end{array}$ & $\begin{array}{l}\text { Approximate Size: } \\
\text { height }(m) / \text { crown breadth }\left(m^{*} m\right)\end{array}$ \\
\hline 1 & Dypsis lutescens & Yellow cane palm & 10 & $2.5 / 1 * 1$ \\
\hline 2 & Bentinckia nicobarica & Bentinck palm & $\begin{array}{l}8 \\
4\end{array}$ & $\begin{array}{l}7.5 / 1 * 1 \\
8 / 1.3 * 1.5\end{array}$ \\
\hline 3 & Hopea odorata & Chengal pasir & $\begin{array}{l}3 \\
2 \\
1\end{array}$ & $\begin{array}{l}3.5 / 2^{\star} 2 \\
2.8 / 1.5^{\star} 1.5 \\
4 / 2.5^{\star} 2.5\end{array}$ \\
\hline 4 & Plumeria rubra & Red frangipani & $\begin{array}{l}1 \\
1\end{array}$ & $\begin{array}{l}1.5 / 0.8^{*} 0.8 \\
2 / 1.2^{*} 1.2\end{array}$ \\
\hline 5 & Cinnamomum camphora & Camphor tree & $\begin{array}{l}1 \\
1 \\
\end{array}$ & $\begin{array}{l}15 / 10^{*} 8 \\
8 / 7^{*} 6.5\end{array}$ \\
\hline 6 & Ixora spp. & Jungle flame & 2 & $0.8 / 1.5 * 1.5$ \\
\hline 7 & Asplenium nidus & Bird's nest fern & 1 & -- \\
\hline 8 & Cycas Revoluta & Sago palm & 1 & $1 / 1 * 1$ \\
\hline 9 & Ficus elastica & Indian rubber tree & 1 & $0.9 /--$ \\
\hline 10 & Ixora sunkist & Flame of woods & & $0.4 /--$ \\
\hline 11 & -- & -- & -- & $0.15 /--$ \\
\hline
\end{tabular}

\subsection{Findings of site observation}

Based on the findings in the open space in the Faculty of Medicine and other open spaces in several public and private universities in Kuala Lumpur. The results of observations have demonstrated that the potential of surrounding open spaces for improving sensory stimulation to support outdoor experience can be estimated from the following aspects:

The size of open spaces and facilities: Some open spaces are simply too small to have facilities for recreation or being accessible. With the area about 2 to $5 \mathrm{~m}^{2}$, these open spaces can be fully occupied by one or two flowerpots and few small plants.

Potential of having easy access: Some open spaces are surrounded by walls of buildings and don't have any entrance or linked path. Such kind of public spaces is arranged for visual aesthetics provision, which is fixed when the building layout is settled. Therefore, there is no potential for improving accessibility and increasing outdoor activities.

Location and context with outside surrounds: The location and building layout can influence the accessibility of adjacent open spaces. For example, if space is located far from the main buildings or placed in unnoticeable corners, it is difficult for users to access and participate. Such kind of open spaces are always having fewer users and cannot be improved by landscape design approaches afterwards.

Spatial form and environmental context: Microclimate variation within the open spaces are linked to the spatial structure of open spaces. Under hot-humid climate, built shapes and configurations, orientation, made envelope and layout, building fabric and surface materials, and natural features like vegetation and water features are determinant for thermal performance (Boukhelkhal \& Bourbia, 2016).

The functions of open spaces: The tasks of adjacent open spaces of buildings are to provide outdoor space for entrance transportation, parking lot, recreation and exercise, or merely for safety and comfort. Some of the functions are not designed for outdoor experience provision but other essential purposes such as parking, emergent evacuation, and safety.

Potential for improving: As for a part of the adjacent greening of academic buildings, the form and function of the courtyard can be influenced by the style or layout of building design rather than the design of itself.

Additional findings of the appliance of local species will contribute to define the variables of sensory design, which is interpreted in the discussion.

\subsection{Discussion}

According to the investigation results, the observation of sensory design is found to be reasonable to separate into two sections: educational buildings and open spaces. This section explains the recorded items and relevant interpretations in respective guidelines based on the findings mentioned above.

\subsection{Guidelines of observation in educational buildings in a university campus}

To explore the settings in the built environment, the first stage of observation shall focus on the description of selected educational buildings, the guideline form shall cover the information about the physical settings and environmental context (see Table 5.1).

Table 5.1: Observation guidelines for building design

\begin{tabular}{|l|l|}
\hline $\begin{array}{l}\text { Context of buildings layout and open } \\
\text { space: }\end{array}$ & $\begin{array}{l}\text { This is to describe the location/scale/orientation/greening design/vegetation of the education department by maps } \\
\text { and verbal description. The location and orientation can influence the thermal comfort of open space. Besides, } \\
\text { the appropriate vegetation selection in landscape design is capable of reducing outdoor air temperature in hot- } \\
\text { humid climates. }\end{array}$ \\
\hline $\begin{array}{l}\text { Façade design and internal structure of } \\
\text { buildings }\end{array}$ & $\begin{array}{l}\text { The architecture style and construction structure of the adjacent building(s), such as facade design, inner } \\
\text { structure, enclosure, building fabric, and surface materials, total floorage, are important to understand its } \\
\text { interaction with open space (Jamaludin et al., 2016). }\end{array}$ \\
\hline
\end{tabular}




\begin{tabular}{|l|l|}
\hline Area and ratio & $\begin{array}{l}\text { For further evaluation about the performance of thermal comfort and the influence on microclimate, the natural } \\
\text { ventilated or non-air ratio and the areas of total building layout, entire floors, open corridor, and lobby are } \\
\text { measured and calculated as essential references. }\end{array}$ \\
\hline Number of students and staff & To predict the potential number of regular users and confirm the sampling amount. \\
\hline Regular lecture hours & $\begin{array}{l}\text { To investigate the possible time of outdoor experience and to define the proper timetable for further observation } \\
\text { in adjacent open spaces. }\end{array}$ \\
\hline Programs setting and research areas & $\begin{array}{l}\text { Most of the educational buildings in the university are divided into scientific and social studies divisions, and } \\
\text { different professions, academic subjects, and research programs may influence the requirement of environment } \\
\text { and equipment. }\end{array}$ \\
\hline $\begin{array}{l}\text { The function settings of open spaces and } \\
\text { potential for outdoor experience provision: }\end{array}$ & To select suitable adjacent open spaces in educational buildings for the case study. \\
\hline
\end{tabular}

\subsection{Guidelines of observation in selected open space}

As the second stage, after conducting observation in campus open spaces, the spatial features and sensory design need to be covered in guidelines, as shown in Table 5.2 .

Table 5.2: Observation guidelines for building design

\begin{tabular}{|l|l|}
\hline $\begin{array}{l}\text { Layout and spatial location with building } \\
\text { and site context }\end{array}$ & $\begin{array}{l}\text { The interaction and connection with the outdoor environment and indoor are essential concerns of open space } \\
\text { design. }\end{array}$ \\
\hline Area and ratio & $\begin{array}{l}\text { For getting the ratio and area of soft and hard landscape and the proportion of open space area in total building } \\
\text { layout to provide data for survey and discussion about thermal comfort performance. }\end{array}$ \\
\hline Plants species and human-made features & $\begin{array}{l}\text { Since the setting of vegetation can affect users' behaviour and activity engagement. The appropriate vegetation } \\
\text { selection may contribute to a better thermal comfort by reducing outdoor air temperature, shading for preventing } \\
\text { solar radiation and creating a relaxing atmosphere. }\end{array}$ \\
\hline Accessibility and participation description & $\begin{array}{l}\text { For investigating the regular activities of users, the ways of participation, the population of daily visitors, preferable } \\
\text { time for using and length of engagement to study the pattern and regularity of involvement (Thompson et al., } \\
2014) \text {. }\end{array}$ \\
\hline $\begin{array}{l}\text { Sensory stimulation in the presence of } \\
\text { open space between buildings }\end{array}$ & $\begin{array}{l}\text { Considering the participant feature of courtyard users in the education area, the stimulated senses are } \\
\text { represented in terms of sight, texture, touch, smell, sound, shadow casting, microclimate, and temperature (Omar } \\
\text { \& Hussein, 2017). }\end{array}$ \\
\hline Feedback from the users & $\begin{array}{l}\text { This item is combined with a questionnaire to get to know the direct feelings from users during participation from } \\
\text { the aspects of problems encountered, the purpose of use, and benefits obtained. }\end{array}$ \\
\hline Potential as a case study & $\begin{array}{l}\text { It is to find out whether an adjacent open space is suitable to be taken as a case study site or not. Based on the } \\
\text { criteria of case study selection mentioned before, the potential for being a case study will be assessed after the } \\
\text { investigation of all the adjacent open spaces in centres of responsibility. }\end{array}$ \\
\hline
\end{tabular}

\subsection{Conclusion \& Recommendations}

The adjacent open spaces of educational buildings are relatively more convenient to use and easier to access, which give them the potential to provide more outdoor experience for students and staff. Their quality can be improved by considering sensory stimulation for the provision of outdoor experience. Therefore, the relevant landscape approaches shall be proposed to construct salutogenic open spaces in urban universities. This strategy will contribute to the promotion of wellbeing and increasing the occupancy of limited green open space.

However, based on the limitations of site observation, there is inadequate information about the interaction between settings and behaviours, and how it related to users' sensory perceptions. Thus, further investigations by conducting a questionnaire survey and behaviour mapping are recommended to explore environmental satisfaction and behaviour settings for obtaining more analysis of sensory perception, open space design and outdoor experience.

\section{Acknowledgement}

Sincere thanks to my supervisors who are the co-authors and my friend Azreen Ishak.

\section{References}

Boukhelkhal, I., \& Bourbia, P. F. (2016). Thermal Comfort Conditions in Outdoor Urban Spaces: Hot Dry Climate -Ghardaia- Algeria. Procedia Engineering, 169, 207215. https://doi.org/10.1016/j.proeng.2016.10.025

Creswell, J.W.; Creswell, J. D. (2017). Research design: qualitative, quantitative, and mixed methods approaches (5th ed.). California: SAGE Publications.

Ghazali, R., \& Abbas, M. Y. (2012). Assessment of Healing Environment in Paediatric Wards. Procedia - Social and Behavioral Sciences, 38(December), 149-159. https://doi.org/10.1016/j.sbspro.2012.03.335

Gonzalez, M. T., \& Kirkevold, M. (2016). Design Characteristics of Sensory Gardens in Norwegian Nursing Homes: A Cross-Sectional E-Mail Survey. Journal of Housing for the Elderly, 30(2), 141-155. https://doi.org/10.1080/02763893.2016.1162252 
Hussein, H. (2010). Using the sensory garden as a tool to enhance the educational development and social interaction of children with special needs. Support for Learning, 25(1), 25-31. https://doi.org/10.1111/j.1467-9604.2009.01435.x

Hussein, H., Omar, Z., \& Ishak, S. A. (2016). Sensory Garden for an Inclusive Society. Asian Journal of Behavioral Studies, 1(4), 33. https://doi.org/10.21834/ajbes.v114.42

Ibrahim, I., Yusoff, W. Z. W., \& Bilal, K. (2012). Space Management: A Study on Space Usage Level in Higher Education Institutions. Procedia - Social and Behavioral Sciences, 47, 1880-1887. https://doi.org/10.1016/j.sbspro.2012.06.917

Jamaludin, A. A., Hussein, H., Keumala, N., \& Mohd Ariffin, A. R. (2016). Preferences of student residents towards sustainability with the concept of bioclimatic design. Planning Malaysia, (5), 145-156. https://doi.org/10.21837/pmjournal.v14.i5.199

Kawulich, B. B. (2005). Participant observation as a data collection method. Forum Qualitative Sozialforschung, 6(2), 1-19. https://doi.org/10.17169/fqs-6.2.466

Malek, N. A., Mohammad, S. Z., \& Nashar, A. (2018). Determinant factor for quality green open space assessment in Malaysia. Journal of Design and Built Environment, 18(2), 26-36

Muslim, M. H. F., Hosaka, T., Numata, S., \& Yahya, N. A. (2017). Nature-Related Experiences during Childhood in Urban and Rural Areas : A First Look at Peninsular Malaysians. Urban Studies Research, 2017, 1-9. https://doi.org/10.20944/preprints201701.0104.v1

Nasir, R. A., Ahmad, S. S., \& Ahmed, A. Z. (2012). Psychological Adaptation of Outdoor Thermal Comfort in Shaded Green Spaces in Malaysia. Procedia - Social and Behavioral Sciences, 68(November), 865-878. https://doi.org/10.1016/j.sbspro.2012.12.273

Nasir, R. A., Sh Ahmad, S., \& Zain Ahmed, A. (2016). The Relationship of Physical Activity and Human Comfort in Urban Park. Asian Journal of Behavioral Studies, 1(2), 36. https://doi.org/10.21834/ajbes.v1i2.31

Omar, Z:; Hussein, H. (2017). Therapeutic Sensory Stimulation Garden: An introduction by BAKTI-MIND Project. Badan Amal dan Kebajian Tenaga Isteri-Isteri.

Othman, A. R., \& Fadzil, F. (2015). Influence of Outdoor Space to the Elderly Wellbeing in a Typical Care Centre. Procedia - Social and Behavioral Sciences, 170, 320329. https://doi.org/10.1016/j.sbspro.2015.01.042

Othman, A. R., \& Fadzil, F. (2018). Impact of Outdoor Space towards the Elderly Wellbeing at Rumah Ehsan Kuala Kubu Bharu. Asian Journal of Behavioral Studies, 3(12), 91. https://doi.org/10.21834/ajbes.V3i12.126

Thompson, C. W., Aspinall, P., \& Roe, J. (2014). Access to Green Space in Disadvantaged Urban Communities: Evidence of Salutogenic Effects Based on Biomarker and Self-report Measures of Wellbeing. Procedia - Social and Behavioral Sciences, 153, 10-22. https://doi.org/10.1016/j.sbspro.2014.10.036

UM in UI Greenmatric World University Rankings. (2019). University of Malaya. Retrieved May 7, 2019, from https:/lips.um.edu.my/aboutum/umique/sustainability@um/um-in-ui greenmetric-world-university-rankings

Wang, M., \& Li, Y. (2018). The Thinking about Water-Enjoyable-Space Design of Urban Waterfront Landscape. 83(Snce), 212-218. https://doi.org/10.2991/snce18.2018.44 